\title{
ATYPICAL PSEUDOCHOLINESTERASE ACTIVITY: A REVIEW AND PRESENTATION OF TWO CASES ${ }^{\circ}$
}

\author{
D. L. ZoERB, M.D. †
}

ATYPICAL pseudocholinesterase activity giving rise to prolonged apnoea following a single intravenous injection of succinylcholine is not a common problem to the practising anaesthetist. When encountered it is readily treatable. Nevertheless, a definitive diagnosis should be made if this unusual response is encountered. Because of the familial incidence of this abnormal enzyme, if the patient's serum shows the presence of atypical pseudocholinesterase activity a study should be done of all living blood relatives. Those whose tests are positive can then be provided with cards warning other physicians of the likelihood of an abnormal response.

This paper is a brief review of the discovery of atypical pseudocholinesterase activity as a cause of prolonged apnoea after succinylcholine, its detection in patient sera, and the hereditary behaviour of this enzyme. Studies of two families which carry the enzyme will be presented.

Succinylcholine is well known to all anaesthetists as a depolarizing muscle relaxant of short duration, lasting two to four minutes. The short duration of action is the result of rapid hydrolysis by a liver enzyme which is referred to as "serum" or "pseudo" cholinesterase. Its activity in serum can be measured. Pseudocholinesterase was first demonstrated in 1935 by Vahlquist. ${ }^{1}$ In 1940 Alles and Hawes $^{2}$ showed that a cholinesterase exists also in red blood cells. This cholinesterase is known as "true" or "specific" cholinesterase, and its purpose is the hydrolysis of acetylcholine.

Since its first use as a muscle relaxant in man in 1951, reports have appeared in the literature of prolonged apnoea following a single intravenous injection of succinylcholine. In the first reports, this phenomenon was attributed to many factors. Respiratory depression due to premedication and thiopental sodium combined with hyperventilation, acidaemia, possible synergism with thiopental sodium, and overdosage were all implicated. Evans et al. in $1952^{3}$ showed that the duration of apnoea following the administration of succinylcholine was approximately inversely proportional to the pseudocholinesterase level in plasma. As a result, it was suggested by them that succinylcholine should not be given in cases where pseudocholinesterase activity was expected to be low, as in liver disease, malnutrition, severe anaemia, and poisoning by organophosphorus compounds. Depression of pseudocholinesterase levels had also been reported in hyperpyrexia, cardiac failure, uraemia, malignancy of the alimentary tract, and

'Presented as part of the Residents' Programme at the Annual Meeting of the Canadian Anaesthetists' Society in Montreal, June 1967.

†Department of Anaesthesia, University Hospital, Saskatoon, Saskatchewan. 
certain infectious diseases. Forbat et al. in $1953^{4}$ pointed out that other mechanisms, such as central nervous system depression, changes in electrolytes, and changes in the excitability of nerves and muscles, may produce long-continued apnoea after succinylcholine even if the pseudocholinesterase level is normal.

To add to the confusion at that time, several cases were reported in which none of the above-mentioned factors applied. Patients were encountered who appeared to be in good health and yet showed prolonged apnoea following succinylcholine and a correspondingly low pseudocholinesterase level. Forbat ${ }^{4}$ presented male siblings with low pseudocholinesterase and felt that if this could not be explained by disease, malnutrition, or poisoning, the families of these patients should be investigated for a hereditary or possibly racial basis of an abnormally low pseudocholinesterase level.

From that time on, the familial incidence of a non-pathological cause of prolonged apnoea following succinylcholine became more apparent. Lehmann and Ryan in $1956^{5}$ presented a study of five families, of apparently healthy individuals, who showed a strong familial incidence of an "idiopathic" low pseudocholinesterase level. The authors suggested that a recessive gene was responsible. Kalow, in his first communication in 1956, ${ }^{6}$ supported the findings of Lehmann and Ryan and mentioned that Gunn had done some family studies on mental patients. $\mathrm{He}$ noted that his own data suggested the existence of at least two types of human pseudocholinesterase. However, it was not until two years later that Kalow and Davies $^{7}$ confirmed the existence of a normal or usual pseudocholinesterase and an atypical form of the enzyme.

The use of dibucaine inhibition by Kalow and Genest ${ }^{8}$ on human serum for the detection of atypical pseudocholinesterase activity was the breakthrough for the classification of patients for genetic study. They noted that in addition to the previously observed quantitative variation in the activity of pseudocholinesterase from person to person, there existed also a qualitative variation of enzyme activity. This could be expressed in differences of substrate specificity and susceptibility to inhibition. By this means patients with the atypical form of enzyme activity could be distinguished from those with mere low pseudocholinesterase activity resulting from any of the previously mentioned pathological states. The local anaesthetic dibucaine (Nupercaine ${ }^{\circledR}$ ) was found to be one of many inhibitors with reduced effectiveness against the atypical enzyme.

The technique of determining the dibucaine number consists essentially of measurements by ultraviolet spectrophotometry of the esterase activity of diluted human serum, using benzoylcholine as the substrate. The normal enzyme hydrolyzes the substrate benzoylcholine, and the disappearance of this substrate is measured. When dibucaine is added to the benzoylcholine-enzyme system, the normal enzyme has a great affinity for dibucaine and a non-activated complex is formed. As a result, less benzoylcholine is hydrolysed (Fig. 1a). The rates of hydrolysis of benzoylcholine in the absence and in the presence of dibucaine are measured. The percentage inhibition is calculated, and this is the dibucaine number. The abnormal enzyme has only about $1 / 200$ the affinity for dibucaine that the normal enzyme has. When the abnormal enzyme is encountered there is less inhibition of the hydrolysis of benzoylcholine by dibucaine (Fig. 2a). A 
given concentration of dibucaine inhibits a normal pseudocholinesterase by about 80 per cent (Fig. $1 b$ ) and the atypical or abnormal enzyme by about 20 per cent (Fig. $2 b$ ).

(a)

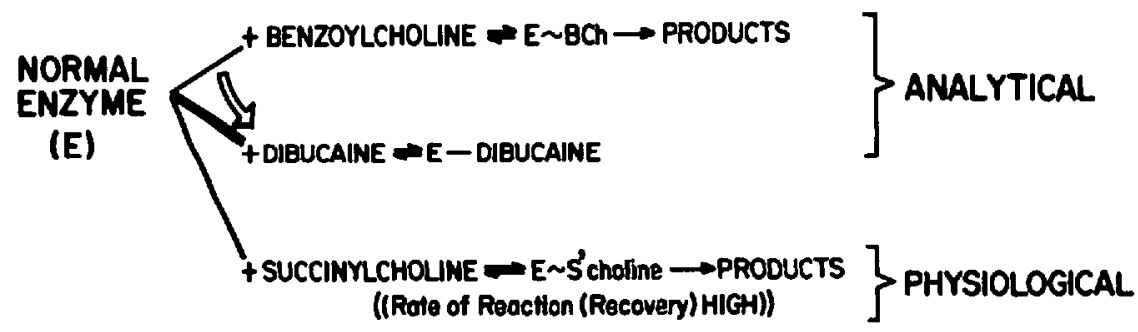

(b)

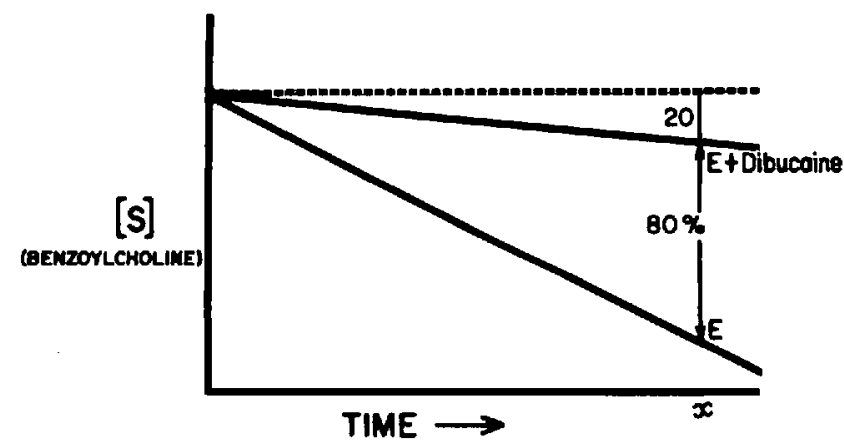

Figure 1. Dibucaine inhibition of pseudocholinesterase.

(a)

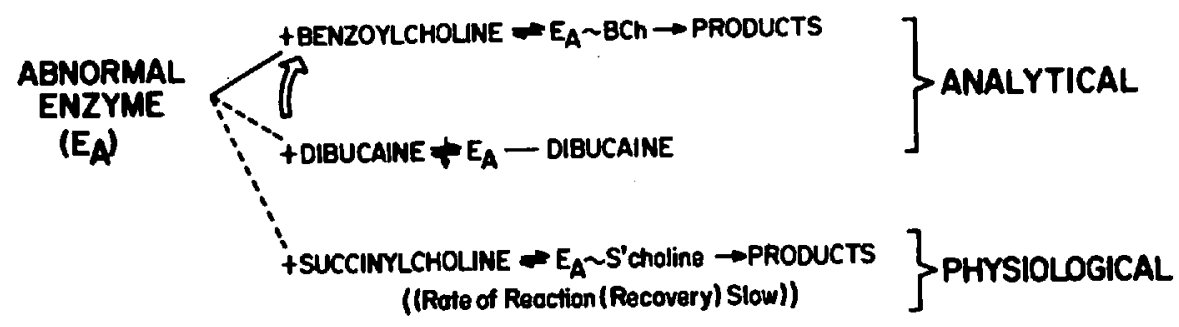

(b)

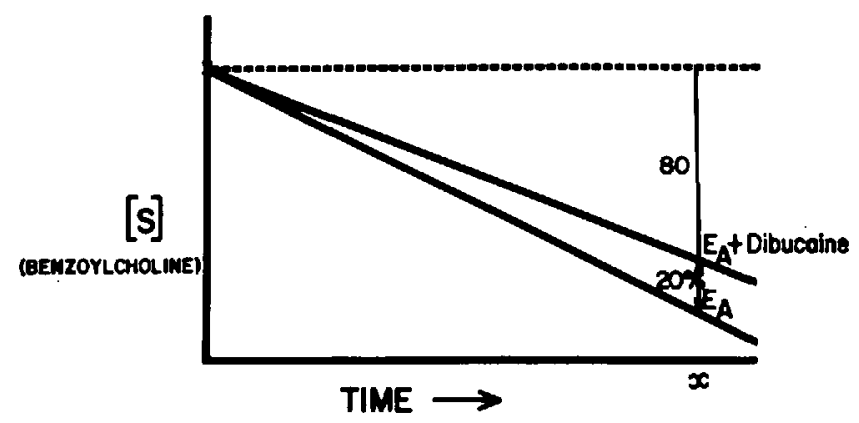

Figune 2. Dibucaine inhibition of atypical pseudocholinesterase. 
The dibucaine number does not depend on the esterase level, and the degree of inhibition is constant for any one individual. Based on the study of a number of human sera, it was found that the dibucaine numbers fell into three fairly distinct groups. There is no general agreement as to the borderline where dibucaine numbers cease to be "normal" and are to be considered as "intermediate," or where "intermediate" values end and "atypical" ones begin. Kalow and Genest considered dibucaine numbers above 70 as "typical" or "normal," between 40 and 70 as "intermediate," and below 20 as "atypical" or "abnormal." On the other hand, Tefler $e t$ al. ${ }^{9}$ and Trew ${ }^{10}$ accept dibucaine numbers below 30 as atypical and go as high as $\mathbf{7 5}$ to include the intermediate group; this classification has been used by us as the basis of interpretation of our cases.

Kalow and Staron in $1957^{11}$ did two extensive family studies and drew some conclusions on the distribution and inheritance of atypical forms of human pseudocholinesterase, as indicated by dibucaine numbers. They noted that the simplest genetic situation which could lead to the three phenotypes was the existence of two allelic autozomal genes without dominance. This would give rise to three genotypes: $(a)$ normal homozygote, $(b)$ heterozygote, and $(c)$ abnormal homozygote. This explanation of inheritance did not, however, completely explain the variation of dibucaine numbers within the three groups. The authors suggested further that there may be two or more allelic genes determining the formation of atypical pseudocholinesterase at different rates, and they raised the possibility of a single type of gene which in turn is influenced by modifying genes.

Harris and Whittaker in $1961^{12}$ reported the presence of two further phenotypes as the result of inhibition of pseudocholinesterase with fluoride. They showed a small sub-group of the intermediate phenotype of the dibucaine number and a similar sub-group of the normal phenotype of the dibucaine number. They suggested that there may be a third gene which can influence a character of the cholinesterase synthetized.

Liddell $^{13}$ and, recently, Hodgkin ${ }^{14}$ have investigated families with complete absence of any pseudocholinesterase activity. It appears that the only explanation for this is the existence of a "silent" gene.

Succinylcholine sensitivity has led to the discovery of inherited variation in pseudocholinesterase. Lehmann and Liddell in $1964^{15}$ emphasized that the genetics of this condition are complex. Their conclusions that at least four allelic genes exist for this human enzyme appears today to be the most widely accepted genetic explanation for the inheritance of pseudocholinesterase activity. The four genes are:

$\mathrm{N}-\mathrm{The}$ "normal" gene (for normal pseudocholinesterase activity).

D-The gene for the atypical variant (recognized by an altered response of the enzyme to the inhibitor dibucaine).

F-A gene for an enzyme with an altered sensitivity to fluoride inhibition.

S-A "silent" gene responsible for complete absence of any pseudocholinesterase activity.

They note that since each individual possesses two allelic genes, these four would then give rise to ten possible genotypes, four in the homozygote group 
ranging from not sensitive to markedly sensitive and six in the heterozygote group ranging from not sensitive to markedly sensitive (Fig. 3 ).

Dibucaine inhibition of patient sera fails to demonstrate all the known genetic variations for the hereditary behaviour of pseudocholinesterase activity. It continues, however, to remain a clinically useful method for determining the presence of atypical enzyme activity in patients and in families of those patients who show prolonged apnoea following single intravenous injections of succinylcholine. Kalow and Gunn in $1959^{16}$ estimated the incidence of this abnormality in a mixed Canadian population on the basis of the three genotypes. About 3 to 4 per cent of the population are heterozygotes (i.e., have intermediate dibucaine numbers), while about one in 2800 is an abnormal homozygote for atypical pseudocholinesterase activity.

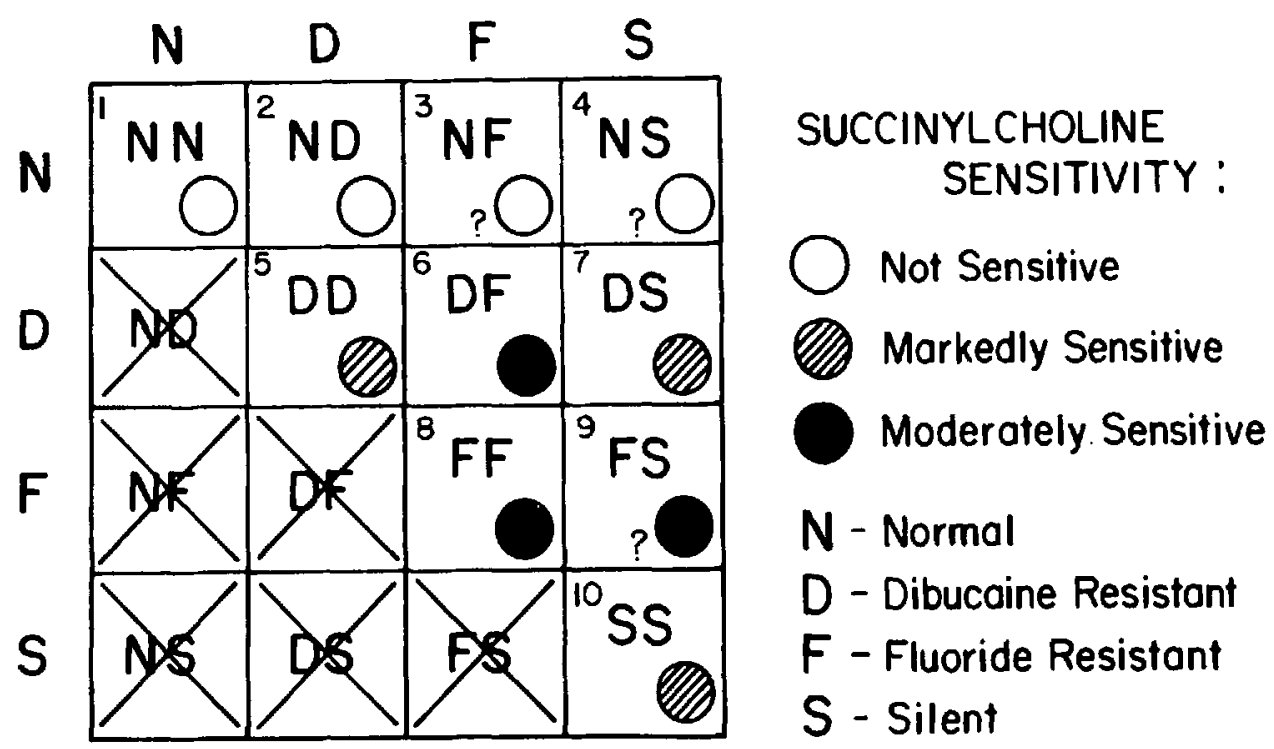

Ficure 3. Possible genotypes determined by the four pseudocholinesterase genes.

\section{Case Reports}

Case No. 1

A 74-year-old male was anaesthetized for the enucleation of a painful blind eye. Premedication was with atropine $0.6 \mathrm{mg}$. intramuscularly one hour and 15 minutes prior to induction. Induction of anaesthesia was with thiopental sodium (2.5\%) $125 \mathrm{mg}$, followed by succinylcholine $40 \mathrm{mg}$. to facilitate endotracheal intubation. It was intended to allow spontaneous respiration with nitrous-oxideoxygen and halothane-ether azeotrope. However, spontaneous respirations did not recur within the usual time and the patient had a period of apnoea lasting 1 hour 45 minutes. His dibucaine number was later found to be 30 . Members of the patient's family were tested and the results are shown in Figure 4.

The patient's three children were found to be heterozygotes as expected. His 


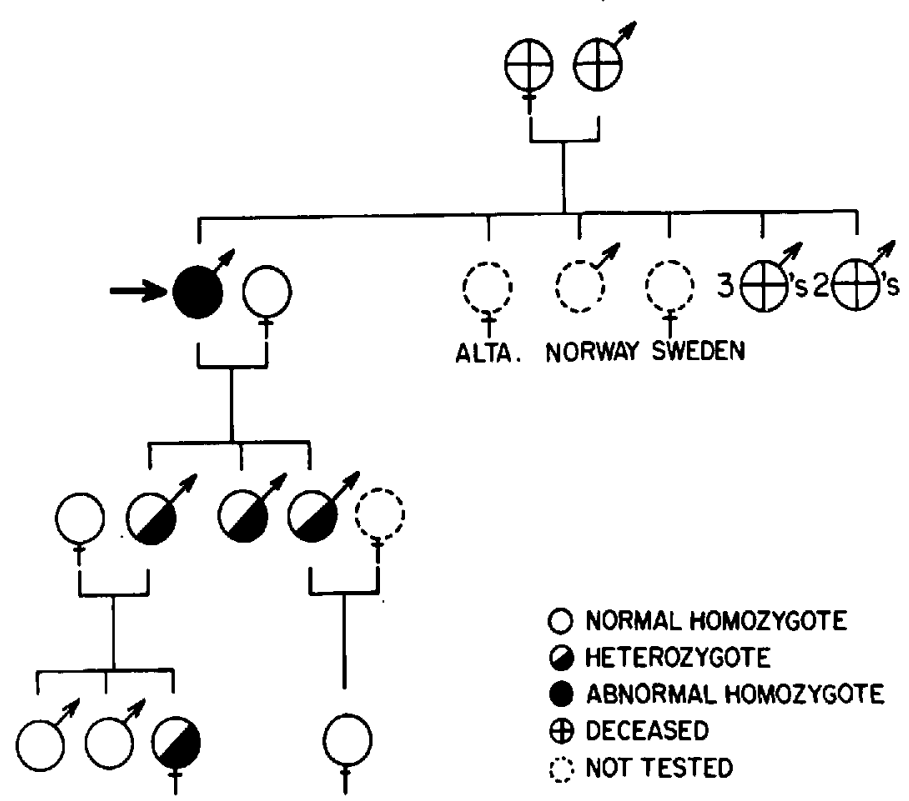

Figure 4. Results of tests for atypical enzyme activity in the family of patient $l$.

wife was a normal homozygote. One grandchild was a heterozygote; three were normal. The three living siblings have not been contacted to date.

Case No. 2

A 59-year-old married woman was anaesthétized for a right brachial arteriogram and upper dorsal sympathectomy. Premedication was with morphine $10 \mathrm{mg}$. intramuscularly and atropine $0.6 \mathrm{mg}$. intramuscularly one hour and 55 minutes prior to induction. Induction of anaesthesia was with thiopental sodium (2.5\%) $250 \mathrm{mg}$., followed by succinylcholine $40 \mathrm{mg}$. to facilitate endotracheal intubation. It was intended to allow spontaneous respiration with nitrous-oxide-oxygen and halothane-ether azeotrope. However, spontaneous respiration did not recur until 40 minutes after induction of anaesthesia. The patient's dibucaine number was found to be 24 .

Her family was tested, and the results are shown in Figure 5. Since the patient was an abnormal homozygote it was expected that her children would all be heterozygotes. However, one was found to be an abnormal homozygote. On the basis of two allelic genes this would not have been possible unless the father was a heterozygote. He was tested, and it was found that this was so. Two of the patient's siblings were found to be abnormal homozygotes and their children are all heterozygotes. Two siblings were found to be heterozygotes and their children were found to be either normal or heterozygotes. One sibling is a normal homozygote. We must assume that the patient's parents were both heterozygotes. If either had been a homozygote, then there should not have been a normal sibling.

This family study helps to stress the point that, as well as the abnormal 


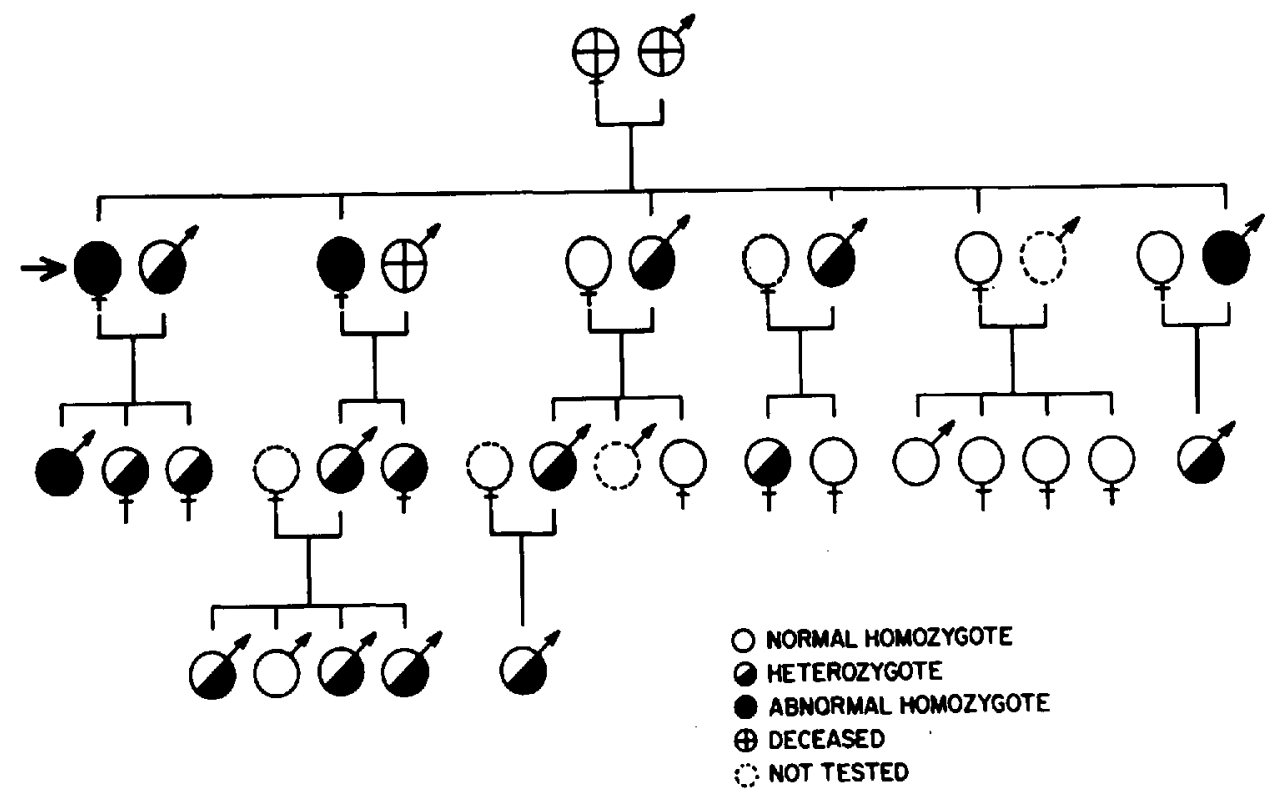

FIGURE 5. Results of tests for atypical enzyme activity in the family of patient 2.

homozygotes, all heterozygotes should be aware of this genetic abnormality, since pairing with another heterozygote could lead to offspring who would be markedly sensitive to succinylcholine.

In the two families, a total of 38 people were studied for the presence of atypical pseudocholinesterase. Five were found to be abnormal homozygotes with dibucaine members in the range of 22 to 30 ; 18 were found to be heterozygotes with dibucaine numbers in the range of 53 to 73; and 15 were found to be normal homozygotes. Of the 15 normals, 14 have dibucaine numbers in the 80 to 84 range while one was reported as 90 .

\section{SUMmary AND ConClusions}

1. The method of Kalow and Genest for the determination of the dibucaine number on patient sera identifies the presence of atypical pseudocholinesterase activity.

2. The usual type of pseudocholinesterase, or an atypical variety of the enzyme, or a mixture of the two may exist in any one individual. Low pseudocholinesterase activity of the usual or normal type is associated with a variety of disease states, while atypical pseudocholinesterase activity is genetically determined.

3. Tests for levels of pseudocholinesterase including determination of the dibucaine number should be conducted on all family members of any patients who have had prolonged apnoea following a single dose of succinylcholine and whose dibucaine number has been shown to be abnormally low. All patients with dibucaine numbers in the intermediate and abnormal range should be regarded as potential candidates for prolonged apnoea after succinylcholine. These people 
should be given cards to carry which should be presented on the occasion of any admission to hospital.

4. Genealogical trees of two families exhibiting the presence of atypical pseudocholinesterase activity are shown.

\section{RÉsumé}

1. La méthode de Kalow et Genest pour déterminer la "dibucaïne number" du sérum du malade signale la présence d'activité de pseudo-cholinestérase atypique.

2. Le type usuel de pseudo-cholinestérase, ou une variété atypique de cette enzyme, ou un mélange des deux peuvent exister chez tout individu. Une faible activité de pseudo-cholinestérase de type normal est liée à un certain nombre d'états pathologiques, alors que l'activité de pseudo-cholinestérase atypique est héréditaire ou familiale.

3. Des épreuves quantitatives de pseudo-cholinestérase comprenant le taux de dibucaïne devraient être pratiquées chez tous les membres d'une famille dont un sujet aurait eu une apnée prolongée à la suite d'une dose unique de succinylcholine, et dont le taux de dibucaine s'est avéré sensiblement plus bas que la normale. Tous les malades dont le "dibucaïne number" se situe dans une zône anormale devraient être considérés comme des sujets aptes à subir une apnée prolongée après la succinylcholine. Ces malades devraient recevoir une carte qu'ils porteraient sur eux continuellement et qu'ils devraient présenter dès qu'ils sont admis dans un hôpital.

4. On montre ici l'arbre généalogique de deux familles qui présentent une activité de pseudo-cholinestérase atypique.

\section{ACKNOWLEDGMENTS}

The author wishes to thank Dr. E. M. Nanson, Professor of Surgery, and Dr. C. C. Ewing, Associate Professor of Ophthalmology, University Hospital, Saskatoon, Saskatchewan, for permission to study their patients. He also wishes to thank Drs. D. M. Ewart, Moose Jaw, Saskatchewan, G. S. Gill, New Westminster, British Columbia, L. N. Gray, Preeceville, Saskatchewan, and A. F. Young, Moose Jaw, Saskatchewan, for assistance in the collection of blood specimens, and Dr. J. A. Trew, Associate Professor of Pathology (Chemical), University Hospital, Saskatoon, Saskatchewan, for technical advice and for carrying out the pseudocholinesterase determinations.

\section{REFERENCES}

I. Vahlquist, B. On the Esterase Activity of Human Blood Plasma. Scandinav. Arch. Physiol. 72: 133 ( 1935).

2. Alles, G. A. \& Hawes, R. C. Cholinesterases in the Blood of Man. J. Biol. Chem. 133: $375(1940)$.

3. Evans, F. T.; Grax, P. W. S.; Lehmann, H.; \& Silk, E. Sensitivity to Succinylcholine in Relation to Serum Cholinesterase. Lancet. $i$ : 1229 (1952).

4. Forbat, A.; Lehmann, H.; \& SilK, E. Prolonged Apnoea Following Injection of Succinylcholine. Lancet. $i i$ : 1067 (1953). 
5. Lehmann, H. \& Ryan, E. The Familial Incidence of Low Pseudocholinesterase Level. Lancet. ii: 124 (1956).

6. KALOW, W. Lancet. ii: 576 (1956).

7. Kalow, W. \& DaviEs, R. O. The Activity of Various Esterase Inhibitors Towards Atypical Human Serum Cholinesterase. Biochem. Pharmacol. 1: 183 (1958).

8. Kalow, W. \& Genest, K. A Method for the Detection of Atypical Forms of Human Serum Cholinesterase. Determination of Dibucaine Numbers. Canad. J. Biochem. Physiol. 35: 339 ( 1957).

9. Tefler, A. B. M.; MacDonald, D. J. F.; \& Dinwoodie, A. J. Familial Sensitivity to Suxamethonium Due to Atypical Pseudocholinesterase. Brit. M. J. i: 153 (1964).

10. Trew, J. A. Personal communication.

11. Kalow, W. \& Staron, N. On Distribution and Inheritance of Atypical Forms of Human Serum Cholinesterase as Indicated by Dibucaine Numbers. Canad. J. Biochem. Physiol. 35: 1305 (1957).

12. Harris, H. \& WhitTaker, M. Differential Inhibition of Human Serum Cholinesterase with Fluoride: Recognition of Two New Phenotypes. Nature, London. 191: 496 (1961).

13. Liddell, J.; Lehmann, H.; \& Silk, E. A Silent Pseudocholinesterase Gene. Nature, London. 193: 561 (1962).

14. Hodckin, W. E.; Giblett, E. R.; Levine, H.; Bauer, W.; \& Motulsky, A. G. Complete Pseudocholinesterase Deficiency: Genetic and Immunologic Characterization. J. Clin. Invest. 44: 486 (1965).

15. LehmanN, H. \& Lmdell, J. Suxamethonium Sensitivity. Brit. M. J. $i: 501$ (1964).

16. Kalow, W. \& GunN, D. R. Some Statistical Data on Atypical Cholinesterase of Human Serum. Ann. Hum. Genet. 23: 239 (1958/59). 